\title{
Genes in their environment: how can we read the riddles?
}

\author{
Andrew Bush*
}

Once upon a time, as all the best children's stories begin, a lot of clever geneticists began a huge hunt for the "asthma gene." At first they thought they had found it, but then more and more of the hunters found different "asthma genes," and sometimes some gene hunters could not find the gene that previous hunters thought was the key one. Life became more and more confusing, and the root causes, which should have been thought of right from the start, have only recently begun to be identified. These include that there are many types of asthma, not likely all to have the same background, and thus careful clinical phenotyping is essential; that genes do not operate in isolation, but in their environment (which includes other genes around them), and this may modify their effects, and even completely reverse them. Also, statistical dangers lie in wait for those who merely collect DNA, feed it all into a good computer and turn the handle; and detailed attention to methodology is needed. The purpose of this editorial is to place the nice study of de Faria et al. ${ }^{1}$ into the context of current issues for genetic association studies.

A recent review ${ }^{2}$ identified more than 30 genes which have been shown to be associated with some aspect of asthma, and the association has been replicated in at least five studies. In broad terms, these fall into one of four groups: genes relating to innate immunity and immunoregulation; genes associated with $\mathrm{TH} 2$ cell differentiation and effector functions; genes associated with epithelial biology and mucosal immunity; and genes associated with lung function, airway remodeling and disease severity. These classes of genes find echoes in our knowledge of the basic immunobiology of asthma. However, the bag is by no means empty; there are now three members of a class of unknown function, encoding transmembrane proteins located in the endoplasmic reticulum, which are implicated in asthma, the latest being ORMDL3. ${ }^{3}$

A number of important methodological issues were discussed which shed light on why so many studies have been conflicting. Linkage studies may implicate a particular locus, for example 5q31-33, but the locus may contain potentially a large number of relevant genes, ${ }^{4}$ and premature conclusions that a particular gene, and not one of its near neighbors, is important must be avoided. It is important to check the validity of the methods used for genotyping, preferably with validation by a second method; and also to check the association in at least one other population. ${ }^{5,6}$ However, it should be noted that if the results do not appear to be important in a second population, this does not mean that the first study is invalid; it should instead provoke a careful look for differences between the studies, which may give important insights into novel gene-environment interactions.

Genes are relatively easy to study, but they exist not in a vacuum but in a complex environment, which the investigator ignores at his peril. Studies in mice have shown that gene-environment interactions may explain more phenotypic variance than either genetic or environmental effects considered separately. ${ }^{7}$ There are many facets to these interactions. Unsurprisingly, the effect of environmental smoke

* MB BS (Hons) MA MD FRCP FRCPCH. Professor of Paediatric Respirology, Imperial School of Medicine, National Heart and Lung Institute, London, UK. Honorary Consultant Paediatric Chest Physician, Royal Brompton Hospital, London, UK.

No conflicts of interest declared concerning the publication of this editorial.

Suggested citation: Bush A. Genes in their environment: how can we read the riddles? J Pediatr (Rio J). 2008;84(3):185-188.

doi:10.2223/JPED.1789 
exposure is greater in children with null polymorphisms in glutathione $\mathrm{S}$ transferases, which are important antioxidant defense genes. ${ }^{8}$ A large number of relatively simple interactions like this have been described. However, the phenomenon of phenotypic plasticity complicates the picture, whereby the effects of a gene may be opposite in different environments. CD14 is a molecule intimately bound up with the response to lipopolysaccharide, and is thus an obvious candidate as an "asthma gene." ${ }^{9}$ However, a meta-analysis reported that the CD14 C-159T polymorphism was not associated with asthma or asthma severity. ${ }^{10}$ When the relationships were studied in more detail, with focused hypotheses, the CD 14/-260 C/T polymorphism in the CD 14 promoter was associated with higher levels of both total and specific IgE to aeroallergens in children in regular contact with domestic pets, but the opposite relationship, not explained by endotoxin levels, in children in contact with stable animals. ${ }^{11}$ Finally, the effects of poverty must not be forgotten; in cystic fibrosis, the most powerful modifying influence on mortality was not genetic, but the wealth of the family. ${ }^{12,13}$ It is better to be rich and ill than poor and ill in many contexts.

There are important interactions within the cell nucleus as well. Polymorphisms in transcription factors may affect gene expression, in an organ specific manner. ${ }^{14,15}$ Polymorphisms in a sequence of genes, each independently of little functional consequence, may synergize to magnify the effect on the risk of a particular phenotype.

Another prerequisite for genetic studies is careful phenotyping of the subjects, and careful selection of controls. Although doctor-diagnosed asthma, bronchial responsiveness and atopy overlap, they are not the same thing, and have different genetic associations. Asthma is a term that has in the past served a useful purpose in ensuring that children wheezing with viral colds were not given antibiotics. However, it may have outlived its usefulness therapeutically, because it may lead to the uncritical and unnecessary prescription of inhaled corticosteroids; and the term "asthma" certainly has in the context of genetic studies, unless it leads inexorably to the question "what sort of asthma." Preschool wheezing phenotypes offer a good example, and even here there is a need for more clarity. Preschool wheeze has been described as transient (present age 0-3 years, not age 3-6 years), persistent (present throughout the first 6 years of life) and late-onset (not present age 0-3 years, present age 3-6 years). ${ }^{16}$ These phenotypes are only of any use retrospectively, since at age 2 , although various indices have been found to predict remission of symptoms, ${ }^{17-19}$ none is much use predicting persistence. They are also an oversimplification albeit one that has clarified our thinking. Recently, more sophisticated mathematical analysis suggests that a more detailed breakdown of wheeze patterns is required. ${ }^{20}$

These epidemiological phenotypes are sometimes uncritically confused with clinical ones; the patterns of intermittent (viral) wheeze and multi-trigger wheeze can be distinguished with a good clinical history, and are sometimes thought to be the same as transient and persistent wheeze respectively, but this has never been shown. It would be naïve to believe that the nonatopic child who wheezes albeit severely three times a year with viral infection has the same underlying genetic makeup as a child with eczema, who wheezes every day.

Even in the school years, there are important international differences. In the western world, atopic asthma is the commonest phenotype, and, although nonatopic asthma exists in the school-age child, it is sufficiently unusual to prompt a careful review of the diagnosis. However, a recent paper from Porto Alegre has shown clearly that this phenotype is much commoner (around 50\%), and associated with early severe bronchiolitis. ${ }^{21}$ This valuable paper underscores the need to be critical about differences between populations apparently suffering from the same disease but in different countries.

There are further complicating factors. Genes may be operative only in a specific time window. ${ }^{22}$ Epidemiological ${ }^{16,23-25}$ and pathological ${ }^{26,27}$ data have suggested that the first three years of life are crucial in determining long-term lung function, and that developmental processes may interact with genes at only specific time points. The inflammatory cellular phenotype of asthma may change over time. ${ }^{28}$ The role of epigenetic modifications in the expression of crucial genes is little explored and may well be important. ${ }^{29}$ The complexities of how genes and the environment (in the widest sense of both) interact to produce the multifaceted asthma phenotypes are far from being understood.

Where do the findings of de Faria et al. ${ }^{1}$ fit into this complex picture? They have nicely generated the hypothesis that TGF- $\beta 1, C D 14$ and IL-4R, but not ADAM33 polymorphisms are implicated in asthma in Brazil. The literature is controversial about the effects of ADAM33, with some reporting important effects ${ }^{30-32}$ and others finding none. ${ }^{33-35}$ These discrepancies, which the present study ${ }^{1}$ can not resolve, are strange; it may reflect the statistical power of the different studies, but it could also reflect population differences and the resolution of the discrepancies may lead to new discoveries. These studies now need taking forward in larger cohorts, to find more genes which apparently have different effects in Brazil than in the western world. Confirmatory studies are important, but the study that produces the unexpected, and is robust, is much more interesting. A prerequisite for success will be the generation of focused hypotheses, and rigorous methodology. This has to include the use of both a discovery and a second replication population. The rewards are potentially very great, because such differences can highlight novel mechanisms; remember that the observation of the protective effect against asthma of being born on a dairy farm, completely counter-intuitive to the received wisdom of 
the time, leads to a whole stream of novel mechanistic papers. We will be watching this space!

\section{References}

1. de Faria IC, de Faria EJ, Toro AA, Ribeiro JD, Bertuzzo CS. Association of TGF- $\beta 1, C D 14, I L-4, I L-4 R$ and ADAM33 gene polymorphisms with asthma severity in children and adolescents. J Pediatr (Rio J). 2008;84:203-10.

2. Vercelli D. Discovering susceptibility genes for asthma and allergy. Nat Rev Immunol. 2008;8:169-82.

3. Moffatt MF, Kabesch M, Liang L, Dixon AL, Strachan D, Heath S, et al. Genetic variants regulating ORMDL3 expression contribute to the risk of childhood asthma. Nature. 2007;448:470-3.

4. Ober C, Hoffjan S. Asthma genetics 2006: the long and winding road to gene discovery. Genes Immun. 2006;7:95-100.

5. Framework for a fully powered risk engine. Nat Genet. 2005;37: 1153.

6. Hall IP, Blakey JD. Genetic association studies in Thorax. Thorax. 2005;60:357-9.

7. Valdar W, Solberg LC, Gauguier D, Cookson WO, Rawlins JN, Mott R, et al. Genetic and environmental effects on complex traits in mice. Genetics. 2006;174:959-84.

8. Kabesch M, Hoefler C, Carr D, Leupold W, Weiland SK, von Mutius E. Glutathione $\mathrm{S}$ transferase deficiency and passive smoking increase childhood asthma. Thorax. 2004;59:569-73.

9. Cleveland MG, Gorham JD, Murphy TL, Tuomanen E, Murphy KM. Lipoteichoic acid preparations of gram-positive bacteria induce interleukin-12 through a CD14-dependent pathway. Infect Immun. 1996;64:1906-12.

10. Kedda MA, Lose F, Duffy D, Bell E, Thompson PJ, Upham J. The CD14 C-159T polymorphism is not associated with asthma or asthma severity in an Australian adult population. Thorax. 2005; $60: 211-4$

11. Eder W, Klimecki W, Yu L, von Mutius E, Riedler J, Braun-Fahrländer C, et al; Allergy And Endotoxin Alex Study Team. Opposite effects of CD 14/-260 on serum IgE levels in children raised in different environments. J Allergy Clin Immunol. 2005;116:601-7.

12. Drumm ML, Konstan MW, Schluchter MD, Handler A, Pace R, Zou F, et al; Gene Modifier Study Group. Genetic modifiers of lung disease in cystic fibrosis. N Engl J Med. 2005;353:1443-53.

13. Schechter MS, Shelton BJ, Margolis PA, Fitzsimmons SC. The association of socioeconomic status with outcomes in cystic fibrosis patients in the United States. Am J Respir Crit Care Med. 2001;163:1331-7.

14. LeVan TD, Bloom JW, Bailey TJ, Karp CL, Halonen M, Martinez FD, et al. A common single nucleotide polymorphism in the CD14 promoter decreases the affinity of Sp protein binding and enhances transcriptional activity. J Immunol. 2001;167: 5838-44.

15. Chavanas S, Bodemer C, Rochat A, Hamel-Teillac D, Ali M, Irvine $A D$, et al. Mutations in SPINK5, encoding a serine protease inhibitor, cause Netherton syndrome. Nat Genet. 2000;25: 141-2.

16. Martinez FD, Morgan WJ, Wright AL, Holberg CJ, Taussig LM. Diminished lung function as a predisposing factor for wheezing respiratory illness in infants. N Engl J Med. 1988;319:1112-7.
17. Castro-Rodríguez JA, Holberg CJ, Wright AL, Martinez FD. A clinical index to define risk of asthma in young children with recurrent wheezing. Am J Respir Crit Care Med. 2000;162: 1403-6.

18. Bacharier LB, Phillips BR, Bloomberg GR, Zeiger RS, Paul IM, Krawiec M. Childhood Asthma Research and Education Network, National Heart, Lung, and Blood Institute. Severe intermittent wheezing in preschool children: a distinct phenotype. J Allergy Clin Immunol. 2007;119:604-10.

19. Devulapalli CS, Carlsen KC, Håland G, Munthe-Kaas MC, Pettersen M, Mowinckel P, et al. Severity of obstructive airways disease by age 2 years predicts asthma at 10 years of age. Thorax. 2008;63:8-13.

20. Henderson J, Sherriff A, Farrow A, Ayres JG. Household chemicals, persistent wheezing and lung function: effect modification by atopy? Eur Respir J. 2008;31:547-54.

21. Pereira MU, Sly PD, Pitrez PM, Jones MH, Escouto D, Dias AC, et al. Nonatopic asthma is associated with helminth infections and bronchiolitis in poor children. Eur Respir J. 2007;29:1154-60.

22. O'Donnell AR, Toelle BG, Marks GB, Hayden CM, Laing IA, Peat JK, et al. Age-specific relationship between CD14 and atopy in a cohort assessed from age 8 to 25 years. Am J Respir Crit Care Med. 2004;169:615-22.

23. Lowe LA, Simpson A, Woodcock A, Morris J, Murray CS, Custovic A; NAC Manchester Asthma and Allergy Study Group. Wheeze phenotypes and lung function in preschool children. Am J Respir Crit Care Med. 2005;171:231-7.

24. Kuehni CE, Strippoli MP, Low N, Silverman M. Asthma in young south Asian women living in the United Kingdom: the importance of early life. Clin Exp Allergy. 2007;37:47-53.

25. Illi S, von Mutius E, Lau S, Niggemann B, Grüber C, Wahn U; Multicentre Allergy Study (MAS) group. Perennial allergen sensitisation early in life and chronic asthma in children: a birth cohort study. Lancet. 2006;368:763-70.

26. Saglani S, Malmstrom K, Pelkonen AS, Malmberg LP, Lindahl H, Kajosaari $\mathrm{M}$, et al. Airway remodeling and inflammation in symptomatic infants with reversible airflow obstruction. Am J Respir Crit Care Med. 2005;171:722-7.

27. Saglani S, Payne DN, Zhu J, Wang Z, Nicholson AG, Bush A, et al. Early detection of airway wall remodelling and eosinophilic inflammation in preschool wheezers. Am J Respir Crit Care Med. 2007; 176:858-64.

28. Fleming L, Wilson N, Regamey N, Bush A. Are inflammatory phenotypes in children with severe asthma stable? Eur Respir J. 2007;30:483S.

29. Vercelli D. Genetics, epigenetics, and the environment: switching, buffering, releasing. J Allergy Clin Immunol. 2004; 113:381-6.

30. Howard TD, Postma DS, Jongepier H, Moore WC, Koppelman GH, Zheng SL, et al. Association of a disintegrin and metalloprotease 33 (ADAM33) gene with asthma in ethnically diverse populations. J Allergy Clin Immunol. 2003;112:717-22.

31. Kedda MA, Duffy DL, Bradley B, O'Hehir RE, Thompson PJ. ADAM33 haplotypes are associated with asthma in a large Australian population. Eur J Hum Genet. 2006;14:1027-36.

32. Foley SC, Mogas AK, Olivenstein R, Fiset PO, Chakir J, Bourbeau J, et al. Increased expression of ADAM33 and ADAM8 with disease progression in asthma. J Allergy Clin Immunol. 2007;119:863-71. 
33. Raby BA, Silverman EK, Kwiatkowski DJ, Lange C, Lazarus R, Weiss ST. ADAM33 polymorphisms and phenotype associations in childhood asthma. J Allergy Clin Immunol. 2004;113:1071-8.

34. Chen C, Huang X, Sheppard D. ADAM33 is not essential for growth and development and does not modulate allergic asthma in mice. Mol Cell Biol. 2006;26:6950-6.
35. Schedel M, Depner M, Schoen C, Weiland SK, Vogelberg C, Niggemann B, et al. The role of polymorphisms in ADAM33, a disintegrin and metalloprotease 33, in childhood asthma and lung function in two German populations. Respir Res. 2006;7:91.

\title{
Systemic infection and brain injury in the preterm infant
}

\author{
Richard A. Polin*
}

In this issue of Jornal de Pediatria, Silveira et al. ${ }^{1}$ investigated risk factors for the development of periventricular leukomalacia (PVL) in a cohort of very low birth weight (VLBW) infants. A significantly greater number of infants with PVL had documented sepsis and/or were ventilated for more than 24 hours. This well-designed study adds supportive evidence for the role of postnatal infection in the pathogenesis of PVL. ${ }^{2}$ While the data are provocative, it is unclear from this article how the timing of the sepsis episodes is related to the development of PVL. If the study infants all had early-onset sepsis, it is somewhat surprising that coagulase negative staphylococcus was the most common pathogen recovered. In the USA that microorganism would be a rare cause of early-onset sepsis. If the study infants had late-onset infections, the question of timing of the infectious episode with the onset of PVL is particularly important. A major limitation in this study is the lack of data on the likelihood of antenatal infection. That question is particularly important given the high rate of bacteremia with Mycoplasma and Ureaplasma in infants born prematurely. ${ }^{3} \mathrm{~A}$ third weakness in this study (as noted by the authors) is the lack of magnetic resonance imaging (MRI) information; MRI is a more sensitive way to diagnose PVL. Given these limitations, however, the authors should be congratulated for addressing this question.
PVL is strongly associated with the development of cerebral palsy. ${ }^{4}$ The pathogenesis of PVL has been linked with disorders resulting in hypoperfusion of the brain (e.g., hypoxia-ischemia, hypotension patent ductus arteriosus with reversed diastolic flow, etc.) and perinatal (antenatal and postnatal) infection. The final common pathway for both etiologies is likely to include microglial activation, cytokine and glutamate release and free radical production (Figure 1).

Late-onset infections are common among VLBW infants and up to $25 \%$ develop a systemic bacterial or fungal infection; 5-10\% have documented meningitis. ${ }^{6}$ Neurological abnormalities are common among survivors. In a recent prospective observational study by Stoll et al. $(n=6,093)^{7}$ preterm infants with proven systemic infections, clinical infection (negative blood culture), necrotizing enterocolitis (NEC) and meningitis were all more likely to exhibit neurological and growth abnormalities compared with an uninfected control group. Hearing impairment was more common in infants with NEC and in those infected with gram-negative microorganisms. In a case-control study, O'shea et al. also noted an association between clinical chorioamnionitis, sepsis and cerebral palsy. ${ }^{8}$

Over the past 10 years, there has been considerable interest in the relationship of antenatal infection and cerebral palsy.

* MD. Professor of Pediatrics, College of Physicians and Surgeons, Columbia University, New York, USA.

No conflicts of interest declared concerning the publication of this editorial.

Suggested citation: Polin RA. Systemic infection and brain injury in the preterm infant. J Pediatr (Rio J). 2008;84(3):188-191.

doi:10.2223/JPED.1784 